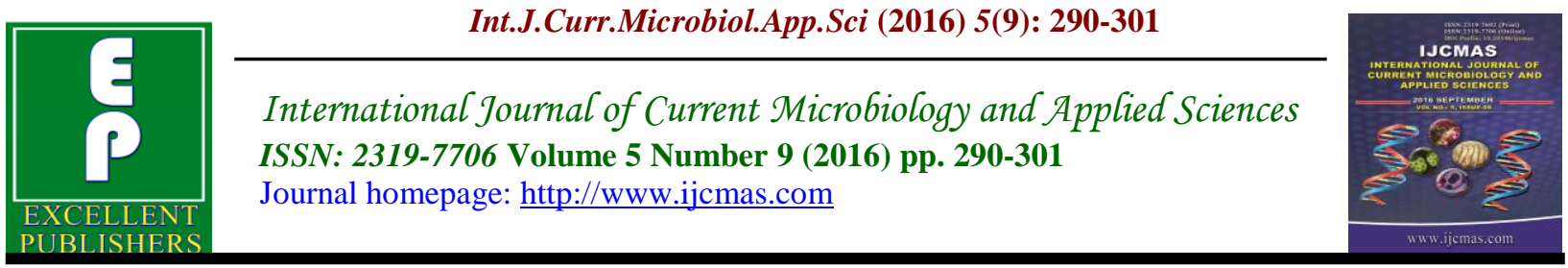

Original Research Article

http://dx.doi.org/10.20546/ijcmas.2016.509.033

\title{
Detection of E.coli, Salmonella spp., and Listeria Monocytogenes in Retail Chicken Meat and Chicken Giblets Samples Using Multiplex PCR in Baghdad City
}

\author{
Kamil M. AL-Jobori*, Mareh L. Mohammed Hasan and Mohammed I. Nader \\ Institute of Genetic Engineering and Biotechnology for Postgraduate Studies, \\ University of Baghdad, Iraq \\ *Corresponding author
}

\section{Keywords}

Multiplex PCR;

Chicken meat;

Escherichia coli;

Salmonella spp.,

Listeria

monocytogenes.

Article Info

Accepted:

13 August 2016

Available Online:

10 September 2016

\section{A B S T R A C T}

Contamination of chicken meat is an important public health problem and food of poultry origin is one of the most common sources of bacterial pathogens. Escherichia coli, Salmonella spp. and Listeria monocytogenes are considered among the most important pathogens which can be spread through meat and meat products consumption. Rapid methods for identification and detection of these dominant foodborne pathogens are still required. This study was conducted to determine the prevalence of these pathogens contamination of imported frozen chicken meat from different origin and locally frozen chicken (leg, breast and giblets) collected over a 6-month period between November and April 2016 from different markets in Baghdad, Iraq. Multiplex polymerase chain reaction (m-PCR) assay for the specific detection of the dominant foodborne bacterial pathogens, including Escherichia coli, Salmonella spp. and Listeria monocytogenes in chicken meat was used. The obtained results indicated that a large percentage of chicken samples $45 \%$ was positive for E. coli, followed Salmonella $17 \%$, and $L$. monocytogenes $11 \%$. The occurrence of $E$. coli was highest in giblets $26(52 \%)$ followed by leg 22(44\%) and breast 19(38\%) samples. The occurrence of S.spp. in leg and giblets were $9(18 \%)$, whilst in giblets $8(16 \%)$ samples. On other hand the occurrence of L. monocytogenes in giblets was 7 (14\%), reduced to 5 (10\%) samples in leg and breast. imported frozen chicken meat samples were the most frequently contaminated by E. coli of origin Turkish 63\% and Brazilian 53\%, followed by Iranian 40\%, and while locally frozen chicken samples were the least frequently contaminated $33 \%$. Samples of origin Turkish and Ukrainian the most frequently contaminated by Salmonella 27 and $20 \%$ respectively, and $L$. monocytogenes $17 \%$, and whilst locally frozen chicken samples were the least frequently contaminated 13 and 7\% respectively. Multiplex PCR was found to be a very sensitive test that allowed rapid and reliable identification of these bacteria.

\section{Introduction}

Poultry meat is one of the most popular food products worldwide. Several nutritional factors such as high level of protein and low fat content and favorable content of unsaturated fatty acids contribute to the 
popularity of poultry meat, of which sensory, dietary and economic factors are important ( Abd El-Aziz, 2013). Outbreaks and Foodborne pathogens pose a significant threat to human public health, leading to a substantial economic burden both in developed and less developed countries (Chen et al., 2012).

More than 250 known foodborne diseases could be caused by food contaminated with bacteria, viruses, parasites, and toxins, which continue to be a public health problem in the world (Ahmed et al., 2014). Of these, bacteria cause a large proportion (approximately 90\%) of all foodborne illnesses. The bacterial pathogens that are most likely to be found in commonly slaughtered livestock (cattle, sheep, and swine) and poultry (chicken and turkey) (Food Safety and Inspection Service, 1999). Chicken meats comprise about the twothirds of the total production in the world (Mead, 2000). Meat and poultry carcasses and their parts are frequently contaminated with pathogens which reach the carcasses from intestinal tract or from fecal material on feet and feathers (Dinçer and Baysa, 2004).

In Iraq and many countries, foodborne pathogens and microbial food safety indicators that are prevalent in poultry, especially, Salmonella, Listeria monocytogenes, and Escherichia coli, have been reported (Kupradit et al., 2013, Rodpai et al., 2013,Saeed et al., 2013, Zhao et al., 2014, Adwan et al., 2015, AL Jobori and Aboodi, 2015,AL- Jobori et al., 2015, ALJobori and AL-Bakri, 2015,Nguyen et al., 2015, Hassan and Hama Saleh,2016).To minimize the prevalence of foodborne diseases and reduce microbial contamination in food supplies, effectively monitoring the occurrence and distribution of bacterial pathogens in food is essential.
The most common tools of standard methods used for pathogen detection are cultural based method, immunological based method, and molecular based methods (Lazcka et al., 2007). Classical cultural methods for the detection of Salmonella spp., Listeria monocytogenes and Escherichia coli are time-consuming and costly. Including step of pre-enrichment and isolation of presumptive colonies of bacteria on solid media, and final confirmation by biochemical and/or serological identification have been applied to detect foodborne pathogens (Lazcka et al. 2007, Xu et al. 2012). These methods are introducing sampling and enumeration errors, as these pathogenic bacteria occur in low numbers. In fact, the low-throughput of these traditional methods does not allow rapid screening of large numbers of food samples for the presence of one or more pathogens (Abubakar et al. 2007). To overcome these limitations, multiplex polymerase chain reaction (m-PCR), real-time PCR, and oligonucleotide arrays have been applied to detect multiple pathogens simultaneously (You et al., 2008; Severgnini et al., 2011). During the last few years, international standards have been agreed the use of PCRbased detection of foodborne pathogens and legislations are implementing new types of analyses as the accepted official methods. For example, European regulation EC 2073/2005 allows the use of alternative detection methods based on certified analyses of international standards (EC, 2005).

Multiplex polymerase chain reaction (mPCR) is a reaction that amplifies more than one target gene simultaneously by mixing multiple primer pairs. mPCR-based methods have been widely used and adapted for the rapid detection of single and multiple bacterial species, for example, Salmonella spp., Escherichia coli, and $L$. 
monocytogenes in meat (Kupradit et al., 2013)in chicken meat ( Zarei et al., 2013). Although mPCR can amplify multiple targets in a single tube, its detection capability is still restricted to only a few targets per assay due to the complexity of the amplification (Wang et al., 2007). For these reasons, typically only 2 ( Radhika et al., 2014, AL Jobori and Aboodi, 2015 ), 3 (Xiao et al., 2014, Zhao et al., 2014,ALJobori et al., 2015, Adwan et al., 2015),4 (Wei et al., 2013), or 5 (Chen et al., 2012) bacterial species are simultaneously detected using m-PCR. However, most research has not combined the detection of Escherichia coli, Salmonella spp. and L. monocytogenes together.

The gene specificity for all the bacteria of interest can be used in the m-PCR to detect each bacterial species. Therefore the objective of this study is to detect the prevalence of Salmonella spp., Escherichia coli, and L. monocytogenes, in frozen raw chicken meat (leg, breast and giblets) using multiplex PCR to take care during cooking and consumption of these products.

\section{Materials and Methods}

\section{Collection of Samples}

During a 6-month period between November and April 2016, a grand total of 150 random samples of frozen chicken meat cuts (leg, breast and giblets) were collected of five origins (Turkish, Iraqi, Iranian, Brazilian and Ukrainian) from different markets at Baghdad governorate.

The collected samples were transferred directly to the laboratory in an ice box with a minimum of delay, and samples were kept frozen until analysis. Thawing of samples occurred during overnight incubation in refrigerator (Roberts and Greenwood, 2003).

\section{Preparation of Samples}

The samples were cut into pieces and 25 grams of the examined samples were weighed aseptically into sterile blender container and $225 \mathrm{ml}$ of nutrient broth were added. Each sample was then homogenized in the blender at $2000 \mathrm{rpm}$ for 1-2 minutes to provide a food homogenate (APHA, 1992). The homogenate was incubated at $37^{\circ} \mathrm{C}$ for $24 \mathrm{~h}$.

\section{DNA Extraction}

A volume of $1.5 \mathrm{ml}$ of the post-enriched sample was centrifuged at $14,000 \mathrm{~g}$ for 1 min, DNA was extracted using Presto Nini $g$ DNA Bacteria Kit according to manufactures' instructions (Geneaid, Korea). The extracted DNA was stored at $-20^{\circ} \mathrm{C}$ until use.

\section{Agarose Gel}

After genomic DNA extraction, agarose gel electrophoresis was adopted to confirm the presence and integrity of the extracted DNA. A $10 \mu$ portion of the sample was analyzed by electrophoresis in agarose gel (2\%), staining with ethidium bromide (Promega USA), and visualized in UV light. A DNA molecular weight standard $100 \mathrm{bp}$ was analyzed alone with the samples (Wang et al., 1997).

\section{PCR Primers}

For m-PCR assay, three primer sets were selected. The primers sequences and their corresponding genes are shown in Table 1.

\section{Multiplex PCR Reaction}

The PCR amplification was performed in a final volume of $25 \mu \mathrm{l}$ containing $4 \mu \mathrm{l}$ of DNA template where $1 \mu \mathrm{l}$ of each primer 
was added, together with $10 \mu$ of nuclease free water, $5 \mu l$ master mix.PCR reactions were performed in a thermal cycler (Eppendorf, Mastercycler Gradient) under the following conditions: initial denaturation at $94^{\circ} \mathrm{C}$ for 5 minutes, denaturation at $94^{\circ} \mathrm{C}$ for 1 minute, primer annealing at $60^{\circ} \mathrm{C}$ for 1 minute, and extension at $72^{\circ} \mathrm{C}$ for 5 minutes. The final cycle included a 10-minute additional extension at $72^{\circ} \mathrm{C}$. PCR products were observed following gel electrophoresis on $2 \%$ agarose gels (Promega,USA) using ethidium bromide staining (Promega,USA).

\section{Results and Discussion}

In the present study, the multiplex PCRbased method was used for detection of three food-borne pathogens after enrichment. The amplifications of the mPCR products were visualized in agarose gel and a 153 base pair fragment (uidR gene ) was identified in the positive samples for the genus $E$. coli; a 284 base pair fragment (invA gene) for the samples belonging to the S. spp. and a 217 base pair fragment (LIS gene ) for the samples belonging to the $L$. monocytogenes. The specificities of these genes (Table 1) were tested using the gDNA templates. Figure 1 shows the data from multiplex assay performed on the three tested pathogens. As shown, after enrichment, the method was able to detect the pathogens at the tested contamination levels in chicken meat (leg, breast and giblets) samples. The prevalence of $E$. coli, Salmonella spp. and L. monocytogenes in different chicken cuts were shown in Table 2 by using this method.

One or more of the bacterial pathogens were detected in 87 of 150 (58\%) samples.In this study, uidR gene was present in 67 samples. The invA gene was present in 26 samples and $L I S$ gene was found in 11 samples.A large percentage of chicken samples $45 \%$ was positive for E. coli, followed Salmonella 17\%, and L. monocytogenes $11 \%$ (Table 2). The occurrence of $E$. coli was highest in giblets $26(52 \%)$ followed by leg $22(44 \%)$ and breast $19(38 \%)$ samples. The occurrence of S.spp. in leg and giblets were 9 (18\%), whilst in giblets 8(16\%) samples. On other hand the occurrence of $\mathrm{L}$. monocytogenes in giblets was 7 (14\%), reduced to $5(10 \%)$ samples in leg and breast (Table 2).

The results given in figure 2 indicated that imported frozen chicken meat samples were the most frequently contaminated by $E$. coli of origin Turkish $63 \%$ and Brazilian $53 \%$, followed by Iranian $40 \%$, and while locally frozen chicken samples were the least frequently contaminated $33 \%$.Samples of origin Turkish and Ukrainian the most frequently contaminated by Salmonella 27 and $20 \%$ respectively, and $L$. monocytogenes $17 \%$, and whilst locally frozen chicken samples were the least frequently contaminated 13 and $7 \%$ respectively.

Contaminations of meat by bacteria have been linked to consumer health problems, as reported by outbreaks and recalls from marketplaces associated with contaminated products. Although classical microbiological methods offer reliable and standardized procedures for the detection of food-borne pathogens (e.g. ISO standards), they often including time consuming analyses that are not always compatible with the need for rapid results. The MPCR based assay was a rapid method and compatible with most methods used to ensure the safety of food products. Bacterial contaminations could be detected specifically depending on the selected primers and the process of determination was much shorter than standard microbiological methods. In this study, multiplex PCR as a rapid and cost- 
effective method, was used for the detection of pathogens in chicken meat.

Triplex PCR method was successfully used to investigate the risk of potential foodborne bacterial contaminations in 150 samples collected from different markets at Baghdad governorate. Our data showed that poultry samples appear to be prominent reservoirs of E. coli, Salmonella, and $L$. monocytogenes(Table 2). Experimental results using specific primer sets showed that three target genes were successfully amplified without nonspecific bands in the triplex PCR, demonstrating the specificity of this method (Figure. 1). The three genera of bacteria (E. coli, Salmonella, and Listeria) targeted in the current study have been associated with food borne infections and diseases as reported by others(Chen et al., 2012; Saeed et al., 2013; Zarei et al., 2013; Zhao et al., 2014, Adwan et al., 2015, Nguyen et al., 2015, Hassan and Saleh, 2016). The authors have previously reported that white cheese, meat, chicken, vegetative, ice cream and beverage samples were contaminated with this pathogens (AL Jobori and Aboodi, 2015,AL- Jobori et al., 2015, AL-Jobori and AL-Bakri, 2015).

As shown in Table 2. a large percentage of chicken samples $45 \%$ was positive for $E$. coli, followed Salmonella $17 \%$, and $L$. monocytogenes $11 \%$. The incidence of $E$. coli and L. monocytogenes were more frequently in giblets than in leg and breast samples. The presence of E. coli in high numbers may be due to improper slaughtering techniques, contaminated surfaces and/or handling of the meat by infected food handlers (Nel et al., 2004). Also, the presence of these pathogens can be due to contamination taking place during the meat processing at slaughterhouse or to the retailers' poor handling of meat (Kagambèga et al., 2012). In the last decade, there has been a wide interest in the use of the multiplex PCR (mPCR) technique. mPCR approaches have been applied to detect different species of several bacteria, to differentiate closely related species and to recognize single species (Settanni and Corsetti, 2007). Most of foodborne pathogens have a zoonotic origin and have reservoirs in healthy food animals from which they spread to an increasing variety of foods. $E$. coli, Salmonella and $L$. monocytogenes are the most common and frequent pathogens responsible for food poisoning and food related infections. According to WHO, 25\% of the diarrhea in foodborne illness is caused by food infected with E. coli (WHO, 2006). The results of the present study revealed that chicken meat can be easily contaminated by $E$. coli. Preparation of healthy chicken meat is very important. We recommend the PCR technique as an accurate, rapid, and safe method for inspection of chicken meat. Providing healthy food has been considered in many countries (Momtaz and Jamshidi, 2013).

Salmonella spp. is among the most important food borne pathogens in the world. Poultry and poultry products are usually causing human salmonellosis outbreaks. Chicken products are widely acknowledged to be a significant reservoir for Salmonella. They have frequently been incriminated as a source of Salmonella contamination and consequently thought to be major sources of the pathogen in humans (Baeumler et al., 2000). Furthermore, one of the commonest causes of Salmonella infection reported in humans has been through the handling of raw poultry carcasses and products, together with the consumption of undercooked poultry meat (Panisello et al., 2000). Salmonella spp. was detected $18 \%$ in leg and breast, and $16 \%$ in giblets samples(Table 2) which may 
interpret due to that the defeathering process may spread microorganisms between carcasses or from the defeathering equipment contributing to an increase in the numbers of psychrotrophs and aerobe mesophiles on the carcasses. The evisceration process provides an opportunity for cross contamination from human, equipments and worker's hands (Jackson et al., 2001). The leading source of contamination of carcasses by Salmonella is the evisceration step at the slaughterhouse (Bouchrif et al., 2009). As well as poor hygiene conditions, regarding the temperature of storage, the equipment and the employees' personal hygiene. The cutting tables were seldom washed or disinfected before use. These benches could therefore be reservoirs from which Salmonella could spread to other equipment through flies or direct contact (Stevens et al., 2006). The extent of Salmonella presence from the fresh raw chicken and frozen chicken were similar; however, significantly more samples were contaminated with Salmonella compared to other categories. The prevalence of Salmonella in the UK poultry was found to be $25-29 \%$ using the cultural methods (Soumet et al., 1999). Using the multiplexPCR method, Salmonella typhimurium and Salmonella enteritidis strains were detected in $30.6 \%$ of environmental swabs of poultry houses in Ploufragan, France (Zarei et al., 2012) Thus, the incidences of Salmonella in Baghdad, Iraq were nearly similar to those reported for the European poultry.

As shown in Table 2, the occurrence of $L$. monocytogenes was highest in giblets $(14 \%)$ followed by leg and breast (10\%). L. monocytogenes can be found in a wide variety of raw and processed foods. Various meats and meat products such as beef, lamb, pork, and chicken, milk and dairy products, seafood and fish products have all been associated with Listeria contaminations (Rocourt and Cossart, 1997 ). We have previously reported that $4 \%$ of white cheese samples contaminated with this pathogen (AL-Joobori and Aboodi, 2015).

Table.1 Microorganisms, target genes, sequences and sizes of the amplified fragments

\begin{tabular}{|c|c|c|c|c|}
\hline Species & $\begin{array}{l}\text { Target } \\
\text { gene }\end{array}$ & PCR primers' sequences $\left(5^{\prime}-3^{\prime}\right)$ & $\begin{array}{l}\text { Product } \\
\text { size }\end{array}$ & References \\
\hline \multirow{2}{*}{$\begin{array}{l}\text { Salmonella } \\
\text { spp. }\end{array}$} & \multirow[t]{2}{*}{$i n v A$} & invA F:GTGAAATTATCGCCACGTTCGG & \multirow[t]{2}{*}{$284 \mathrm{bp}$} & \multirow{2}{*}{$\begin{array}{l}\text { Rahn et al., } \\
1992\end{array}$} \\
\hline & & invA R :TCATCGCACCGTCAAAGG & & \\
\hline \multirow{2}{*}{$\begin{array}{l}\text { Escherichia } \\
\text { coli }\end{array}$} & \multirow[t]{2}{*}{ uidR } & UidR F:TGTTACGTCCTGTAGAAAGCCC & \multirow[t]{2}{*}{$153 \mathrm{bp}$} & \multirow[t]{2}{*}{ Bej et al., 1991} \\
\hline & & R:AAAACTGCCTGGCACAGCAAT & & \\
\hline \multirow[t]{2}{*}{$\begin{array}{l}\text { Listeria } \\
\text { monocytogenes }\end{array}$} & \multirow[t]{2}{*}{ LIS } & LIS F:TCATCGACGGCAACCTCGG & \multirow[t]{2}{*}{217 bp } & \multirow[t]{2}{*}{$\begin{array}{l}\text { Germini et al., } \\
2009\end{array}$} \\
\hline & & LISR:TGAGCAACGTATCCTCCAGAGT & & \\
\hline
\end{tabular}


Table.2 Incidence of E.coli, Salmonella spp and L. monocytogenes in examined samples.

\begin{tabular}{|l|c|c|c|}
\hline \multirow{2}{*}{ Samples } & \multicolumn{3}{|c|}{ Incidence of pathogens mPCR } \\
\cline { 2 - 4 } & E. coli & S. spp & L.monocytogenes \\
\hline Leg & $22(44 \%)$ & $9(18 \%)$ & $5(10 \%)$ \\
\hline Breast & $19(38 \%)$ & $9(18 \%)$ & $5(10 \%)$ \\
\hline Giblets & $26(52 \%)$ & $8(16 \%)$ & $7(14 \%)$ \\
\hline Total & $67(45 \%)$ & $26(17 \%)$ & $17(11 \%)$ \\
\hline
\end{tabular}

Fig.1 Multiplex PCR applied to multiple Pathogen detection Lane M: 100 bp DNA ladder, Lane :1,2,3,4,5,6 Multiple pathogen, E. coli 152 bp, Salmonella 284 bp, and L. monocytogenes 217bp, Lane:7,8 Negative control.

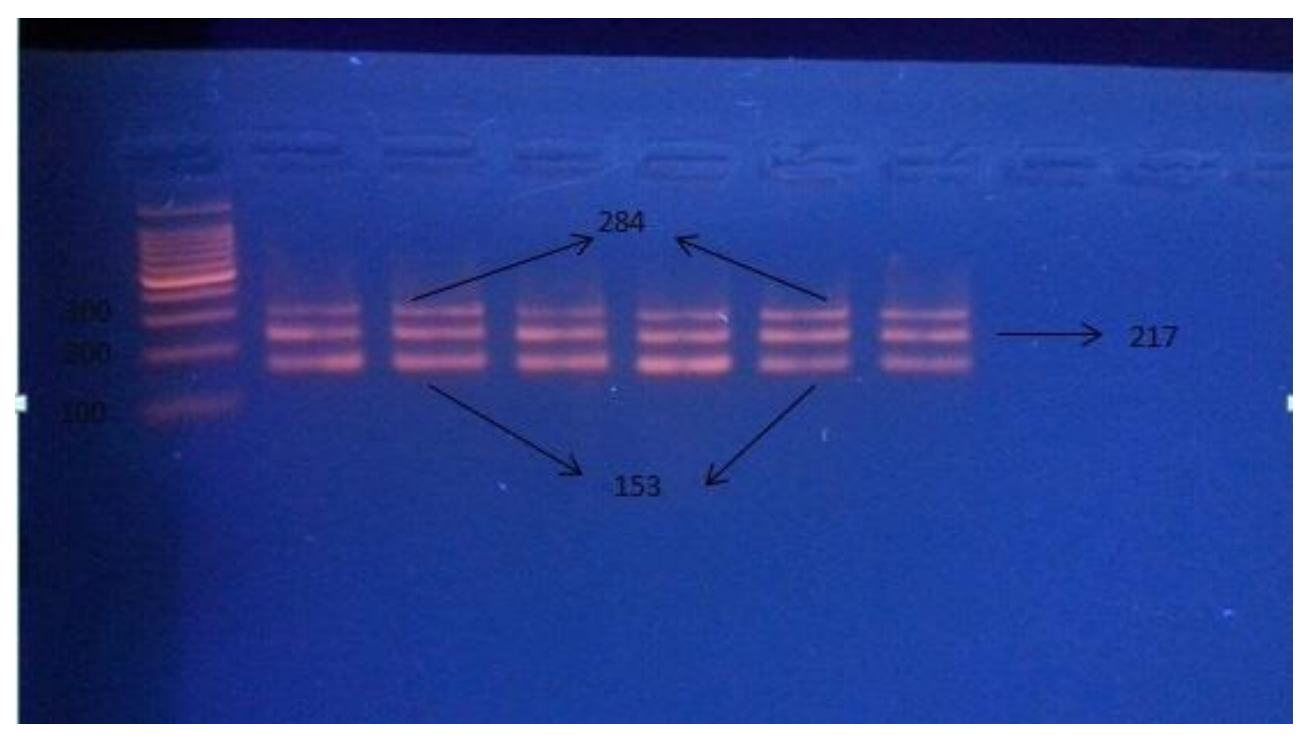

Fig.2 Distribution of E. coli, Salmonella spp. and L. monocytogenes in five selected origin based on results of mPCR.

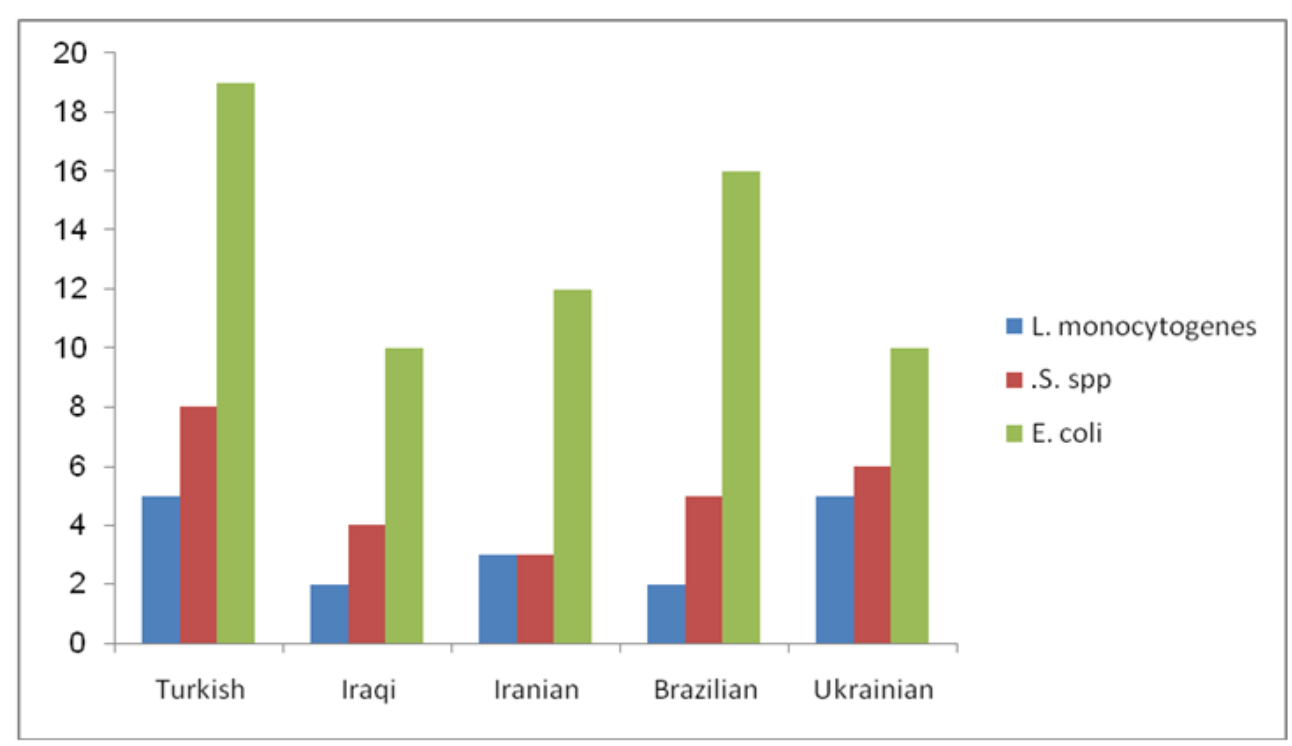


According to the previous reports from Iran, $2.6 \%$ of the beef and $6 \%$ of the lamb samples were contaminated with this pathogen (Jalali and Abedi, 2008).No contamination with L. monocytogenes was reported in 200 beef carcasses, in Northern Ireland (Madden et al., 2001). However, $0.42 \%$ of bison carcasses in USA were contaminated with this pathogen (Li et al., 2004). This is consistent with observations that L. monocytogens can grow over a wide range of environmental conditions such as refrigeration temperatures (Naravaneni and Jami, 2005), which allows it to overcome the food preservation and safety barriers, and creates a potential risk to human health. The prevalence of L.monocytogenes in retail poultry in Leon, Spain, was 32\% (Miettinen et al., 2001). In addition, the difference in prevalence of $L$. monocytogenes in different parts of chicken might be due to the variation in water content and nutrient level of chicken parts. Montville and Matthews (2008) stated that listerial growth is affected by humidity and nutrient contents of the food.

In the present study, $E$. coli was detected in 63and $53 \%$ of origin Turkish and Brazilian followed by Iranian 40\%. Samples of origin Turkish and Ukrainian were the most frequently contaminated by Salmonella 27 and $20 \%$ respectively, and $L$. monocytogenes 17 (Table 2). The differences in these contamination percentages are probably related to numerous factors, including the origin of the chicken lots, the hygiene-sanitary conditions in the abattoirs, and cross-contamination that occurred during plucking, washing, cooling and wrapping, and the way of displayed the product in the markets. When comparing our results to other authors, the discrepancies could be partly due to differences in sampling techniques and the detection methods. Besides, slaughter hygiene, cross contamination of the products at different stages throughout the food chain should be considered. Variations in the prevalence of foodborne pathogens from different food samples in different studies could be due in part to several factors including: differences in the reservoir, ecological origin of pathogenic strains, sensitivity of detection methods, detected genes, number of samples, type of sample time of sampling (Zhao et al., 2001; Adwan et $a l ., 2005)$ and storage conditions. The finding of high level of bacterial contamination as well as the occurrence of virulence factors in food pathogens strongly indicates the need for the implementation of surveillance programs for food products in Iraq. In conclusion, the mPCR is rapid, effective and sensitive method in detection of foodborn pathogens. Contamination of chicken meat and giblets indicate bad microbiological quality of retail chicken which may due to contamination occur during processing or distribution. It is necessary to put more emphasis on meat hygiene. Therefore, the surveillance of potential contaminant bacteria in different kinds of meat is crucial to safeguard the public health.

\section{References}

Abd El-Aziz, D.M. 2013. Detection of Salmonella typhimurium in retail chicken meat and chicken giblets. Asian Pac. J. Trop. Biomed., 3(9): 678-681.

Abubakar, I., Irvine, L., Aldus, C.F., Wyatt, G.M., Fordham, R., Schelenz, S., Shepstone, L., Howe, A., Peck, M., and Hunter, P.R. 2007. A systematic review of the clinical, public health and cost effectiveness of rapid diagnostic tests for the detection and identification of bacterial intestinal pathogens in faeces and 
food. Health Technol. Assess., 11(36): $1-216$.

Adwan, G., Abu-Shanab, B., Adwan, K. 2005. Enterotoxigenic Staphylococcus aureus in raw milk in the North of Palestine. Turkish J. Biol., 29: 229232.

Adwan, G.M., Alqarem, B.R., and Adwan, K.M. 2015. Prevalence of foodborne pathogens in meat samples in Palestine. Int. Food Res. J., 22(5): 1806-1812.

Ahmed, S.M., Hall, A.J., Robinson, A.E., Verhoef, L., Premkumar, P., and Parashar, U.D. 2014. Global prevalence of norovirus in cases of gastroenteritis: a systematic review and meta-analysis. Lancet Infect. Dis., 14: 725-730.

AL- Jobori, K.M., Aboodi, A.H. 2015. Detection of Salmonella spp. and Listeria monocytogenes in soft white cheese using PCR assays. Int. J. Original Res., 1(1): 1-7.

AL-Jobori, K.M., Aboodi, A.H., and Darweesh, M.G. 2015. Evaluation of diagnostic polymerase chain reaction (PCR)for the detection of Escherichia coli, Staphylococcus aureus and Bacillus cereus in cheese. Afr. J. Microbiol. Res., 9(9): 611-616.

AL-Jobori, K.M., and AL-Bakri, A.K. 2015. Comparison between PCR and Culture Methods for Detection of Salmonella typhimurium from Food and Beverage. Donn. J. Food Sci. Tech., 1(2): 6-16.

American Public Health Association (APHA). 1992. Compendium of methods for microbiological examination of Food. 3rd Ed. Brothers, Ann, Arb.

Baeumler, A.J., Hargis, B.M., Tsolis, R.M. 2000. Tracing the origins of Salmonella outbreaks. Sci., 287: 5052.
BeJ, A.K., Joseph, L., Dicesare, Haff, L., and Atlas, R.M. 1991. Detection of Escherichia coli and Shigella spp. in water by using the Polymerase Chain Reaction and Gene Probes for uid. Appl. Environ. Microbiol., 1013-1017.

Bouchrif, B., Paglietti, B., Murgia, M., Piana, A., Cohen, N., Ennaj, M.M., Rubino, S., Timinoun, M. 2009. Prevalence and antibiotic-resistance of salmonella isolated from food in Morocco. J. Infect. Dev. Ctries., 3: 3540.

Chen, J., Tang, J., Liu, J., Cai Z., Bai, X. 2012. Development and evaluation of a multiplex PCR for simultaneous detection of five foodborne pathogens. J. Appl. Microbiol., 112: 823-830.

Dinçer, A.H., and Baysa, T. 2004. Decontamination techniques of pathogen bacteria in meat and poultry. Crit. Rev. Microbiol., 30: 197-204.

European Commission. Commission Regulation (EC) No 2073/2005 of 15 November 2005 on microbiological criteria for foodstuffs. Off. J. Eur. Union L., 338(1).

Food Safety and Inspection Service (FSIS). 1999. microbiological hazard identification guide for meat and poultry components of products produced by very small plants, 1999 . Retrieved from http://www.fsis.usda.gov/Oa/haccp/hig uide.pdf? redirecthttp=true.

Germini, A., Masola, A., Carnevali, P., and Marchelli, R. 2009. Simultaneous detection of Escherichia coli O175: H7, Salmonella spp., and Listeria monocytogenes by multiplex PCR. Food Cont., 20(8):733-738.

Hassan, Kh.I., and Hama Saleh, S.K. 2016. A rapid methods for PCR based on detection of Salmonella spp. and Staphylococcus aureus in spiked and naturally contaminated food. Iraqi $J$. 
Agri. Sci., 47: (Special Issue): 66-73.

Jalali, M., and Abedi, D. 2008. Prevalence of Listeria species in food products in Isfahan, Iran. Int. J. Food Microbiol., 122(3): 336-340.

Kagambèga, A., Martikainen, O.,Lienemann, T., Siitonen, A., Traoré, A.S., Barro, N., and Haukka, K. 2012. Diarrheagenic Escherichia coli detected by 16-plex PCR in raw meat and beef intestines sold at local markets in Ouagadougou, Burkina Faso. Inter. J. Food Microbiol., 153: 154- 158

Kupradit, C., Ruamkuson, D., Rodtong, S., and Ketudat-Cairns, M. 2013. Novel multiplex polymerase chain reaction and an oligonucleotide array for specific detection of the dominant foodborne bacterial pathogens in chicken meat. Afr. J. Microbiol. Res., 7(24): 3085-3095.

Lazcka, O., Del Campo, F., and ũno, F.X. 2007. Pathogen detection: a perspective of traditional methods and biosensors. Biosens. Bioelectron, 22: 1205-1217.

Li, Q., Sherwood, J.S., and Logue, C.M. 2004. The prevalence of Listeria, Salmonell, scherichia coli and E. coli O157: H7 on bison carcasses during processing. Food Microbiol., 21(6): 791-799.

Madden, R.H., Espie, W., Moran, L., McBride, J., Scates, P. 2001. Occurrence of Escherichia coli O157: H7, Listeria monocytogenes, Salmonella and Campylobacter spp. on beef carcasses in Northern Ireland. Meat sci., 58(4): 343-346.

Mead, G.C. 2000. Fresh and furtherprocessed poultry. In: B. M. Lund, T. C. Baird Parker, G. W. Gould (eds). "The Microbiological Safety and Quality of Food". Vol I, Aspen Publ. Gaithersburg, Maryland. Pp.
445-471.

Miettinen, M.K., Palmu, L., Björkroth, K.J., and Korkeala, H. 2001. Prevalence of Listeria monocytogenes in broilers at the abattoir, processing plant, and retail level. J. Food Prot., 64: 994999.

Momtaz, H., and Jamshidi, A. 2013. Shiga toxin-producing Escherichia coli isolated from chicken meat in Iran: Serogroups, virulence factors, and antimicrobial resistance properties. Poultry Sci., 92 :1305-1313.

Montville, T.J., and Matthews, K.R. 2008. Food Microbiology. ASM Press, Washington, DC.

Naravaneni, R., and Jamil, K. 2005. Rapid detection of food-borne pathogens by using molecular techniques. J. Med. Microbiol., 54: 51-54.

Nel, S., Lues, J.F.R., Buys, E.M., and Venter, P. 2004. Bacterial populations associated with meat from the deboning room of a high throughput red meat abattoir. Meat Sci., 66: 667674.

Nguyen, G., Abo-Samaha, M.I., Reddy, G., Abdulrahman, M., Samuel, T., Adesiyun, A., and Abdela, W. 2015. Improved Detection of Campylobacter jejuni, Listeria monocytogenes and Salmonella Typhimurium from Raw Meat Products Using Conventional and Newly Developed TaqMan Assays. Int. J. Poultry Sci., 14(7): 364375.

Panisello, P.J., Rooney, R., Quantick P.C., and Stanwell- Smith, R. 2000. Application of foodborne disease outbreak data in the development and maintenance of HACCP systems. Int. J. Food Microbiol., 59: 221-234.

Radhika, M., Saugata, M., Murali, H.S., and Batra, H.V. 2014. A novel multiplex PCR for the simultaneous detection of Salmonella enterica and Shigella 
species. Brazilian J. Microbiol., 45(2): 667-676.

Rahn, K., Grandis, S.A. De., Clarke, RC., Mcewen, S.A., Galan, J.E., Ginocchio, C., Curtiss, R., and Gyles, C.L. 1992. Amplification of an invA gene sequence of Salmonella typhimurium by polymerase chain reaction as a specific method of detection of Salmonella. Mol. Cellular Probes, 6: 271-279.

Roberts, D., and Greenwood, M. 2003.Practical food microbiology. 3rd ed. Oxford: Blackwell publishing Ltd, p. $58-65$.

Rocourt, J., and Cossart, P. 1997. Listeria monocytogenes. In: M.P. Doyle, L.R.Buechat,and T.J.Montville (eds.)." Food Microbiology-Fundamentals and Frontiers " 2 ed; 1997. p. 337-352.

Rodpai, E., Moongkarndia, P., Tungrugsasutb, W., Phisannoradeja, R., and Kanarat, S. 2012. Comparison of multiplex polymerase chain reaction and immunoassay to detect Salmonella spp., S. Typhimurium, and $S$. Enteritidis in Thai chicken meat. Sci., Asia, 39: 150-159.

Saeed, A.A., Hasoon, M.F., and Mohammed, M.H. 2013. Isolation and Molecular Identification of Salmonella typhimurium from Chicken Meat in Iraq. J. World's Poult. Res., 3(2): 6367.

Settanni, L., and Corsetti, A. 2007. The use of multiplex PCR to detect and differentiate food- and beverage associated microorganisms: A review. J. Microbiol. Meth., 69: 1-22.

Severgnini, M., Cremonesi,P., Consolandi, C., De Bellis,G., and Castiglioni, B. 2011. Advances in DNA microarray technology for the detection of foodborne pathogens. Food Bioprocess Technol., 4: 936-953.

Soumet, C., Ermel, G., Rose, N., Rose, V.,
Drouin, P., Salvat, G., and Colin, P. 1999. Evaluation of multiplex PCR assay for simultaneous identification of Salmonella sp., Salmonella Enteritidis and Salmonella Typhimurium from environmental swabs of poultry houses. Lett. Appl. Microbiol., 28: 113-117.

Stevens, A., Kaboré, Y., PerrierGrosClaude; Jean-David; Millemann, Y., Brisabois, A.,Catteau, M.,Cavin, JeanFrançois, and Dufour, B.(2006). Prevalence and antibiotic-resistance of salmonella isolated from beef sampled from the slaughterhouse and from retailers in Dakar (Senegal). Inter. J. Food Microbiol., 110: 178-186.

Wang, R., Cao, W.W., and Carl, E. 1997. CernigliaPhylogenetic analysis and identification of Shigella spp. by molecular probes. Mol. cellular probes, 11(6): 427-430.

Wang, X.W., Zhang, L., Jin, L.Q., Jin, M., Shen, Z.Q., An, S., Chao, F.H., and Li, J.W. 2007. Development and application of an oligonucleotide microarray for the detection of foodborne bacterial pathogens. Appl. Microbiol. Biotechnol., 76: 225-233.

Wei, B., Cha, S.Y., Kang, M., Park, I. J., Moon, O.K., Park, C.K., and Jang, H.K. 2013. Development and application of a multiplex PCR assay for rapid detection of 4 major bacterial pathogens in ducks. Poultry Sci., 92: 1164-1170.

WHO Global Salm. Surv. 2006. Progress report 2000-2005. Available from: < http://www.who.int/salmsurv/en/> (acc essed 12/06/2007).

Xiao, X., Zhang, L., Wu, H., Yu, Y., Tang, Y., Liu, D., and Li, X. 2014. Simultaneous detection of Salmonella, Listeria monocytogenes, and Staphylococcus aureus by multiplex real-time PCR assays using high- 
resolution melting. Food Anal. Methods, 7: 1960-1972.

Xu, Y., Cui, L., Tian, C., Li, S., Cao, J., Liu, Z., and Zhang, G. 2012. A multiplex polymerase chain reaction coupled with high-performance liquid chromatography assay for simultaneous detection of six foodborne pathogens. Food Control, 25(2): 778-783.

You, Y., Fu, C., Zeng, X., Fang, D., Yan, X., Sun, B., Xiao, D., and Zhang, J. 2008. A novel DNA microarray for rapid diagnosis of enteropathogenic bacteria in stool specimens of patients with diarrhea. J. Microbiol. Meth., 75: 566-571.

Zarei, M., Basiri, N., Jamnejad, A., and Hadi Eskandari, M. 2013. Prevalence of Escherichia coli O157:H7, Listeria monocytogenes and Salmonella spp. in Beef, Buffalo and Lamb using multiplex PCR. Jundishapur $J$. Microbiol., 6(8): 7244-7248.
M. 2012. Prevalence of Listeria monocytogenes, Vibrio parahaemolyticus, Staphylococcus aureus, and Salmonella spp. in seafood products using multiplex polymerase chain reaction. Foodborne Pathog. Dis., 9: 108-112.

Zhao, C., Ge, B., De Villena, J., Sudler, R., Yeh, E., Zhao, S., White, D.G., Wanger, D, and Meng, J. 2001. Prevalence of Campylobacter spp., Escherichia coli, and Salmonella serovars in retail chicken, turkey, pork, and beef from the Greater Washington, D.C., area. Appl. Environ. Microbiol., 67(12): 54315436.

Zhao, H.K., Wang, W.J., Zhao, P., Zhang, H.B., Kong, N., Zhou, M.D., and Zhang, H. 2014. Simultaneous detection of Salmonella, Listeria Monocytogenes and Shigella in Poultry Samples by Triplex PCR. $J$. Bacteriol. Mycol., 1(1): 5.

Zarei, M., Maktabi, S., and Ghorbanpour,

\section{How to cite this article:}

Kamil M. AL-Jobori, Mareh L. Mohammed Hasan and Mohammed I. Nader. 2016. Detection of E.coli, Salmonella spp., and Listeria Monocytogenes in Retail Chicken Meat and Chicken Giblets Samples Using Multiplex PCR in Baghdad City. Int.J.Curr.Microbiol.App.Sci. 5(9): 290-301. doi: http://dx.doi.org/10.20546/ijcmas.2016.509.033 